UDC:339.138:502.3

JEL: M40, 013, Q56

DOI: https://doi.org/10.35774/visnyk2020.02.185

\author{
Olena CHYGRYN, \\ Ph.D., Associate Professor of Marketing \\ Sumy State University \\ 40000, Ukraine, Sumy, Rimsky-Korsakov st., 2 \\ e-mail: o.chygryn@econ.sumdu.edu.ua \\ ODCID ID: https://orcid.org/0000-0002-4007-3728 \\ Lilia LYULYOVA, \\ Phd student, Department of Marketing \\ Sumy State University \\ 40000, Ukraine, Sumy, Rimsky-Korsakov st., 2 \\ e-mail: I.lyulyova@econ.sumdu.edu.ua \\ ODCID ID: https://orcid.org/0000-0002-2912-722X \\ Marina SAENKO, \\ Phd student, Department of Marketing \\ Sumy State University \\ 40000, Ukraine, Sumy, Rimsky-Korsakov st., 2 \\ e-mail: marinchik86@ukr.net \\ ODCID ID: https://orcid.org/0000-0003-4939-6379
}

\title{
MAIN DETERMINANTS OF GREEN COMPETITIVENESS
}

Chygryn O., Lyulyova L., Saenko M. (2020). Holovni determinanty staloi konkurentospromozhnosti [The main determinants of green competitiveness]. The Herald of Ternopil National Economic University, Vol. 2. P. 185-193. DOI: https://doi.org/10.35774/ visnyk2020.02.185

Чигрин О., Люльова Л., Саєнко М. Головні детермінанти сталої конкурентоспроможності. Вісник Тернопільського національного економічного університету. 2020. Вип. 2. С. 185-193. DOI: https://doi.org/10.35774/visnyk2020.02.185

\section{Abstract}

Introduction. The development of the business sector is characterized by the tendency of many enterprises to promote environmentally friendly strategies, implement sustainable development goals, which will help solve global and local environmental problems, reduce

(C) Olena Chygryn, Lilia Lyulyova, Marina Saenko, 2020. 
anthropogenic pressure on the environment, save resources, form competitive development of the country and business sector as a whole.

The purpose of the article is to study scientific approaches to determining the main factors and components of sustainable competitiveness, defining key goals (target groups) and determinants that will determine the subject basis of appropriate marketing strategies to ensure the green competitiveness of enterprises.

Results. In order to form strategic guidelines for promoting green competitiveness, the article has systematized scientific approaches to its research, which include marketing, technology, innovation, communication, stakeholder, quality, level, financial and ethical areas.

The authors have emphasized that the processes of providing environmentally friendly competitive advantages are largely determined by a set of appropriate determinants. The article proposes to create two groups of the relevant determinants, which will be determined by objective (external) and subjective (internal) components. The system of relevant factors is proposed to be classified according to managerial, financial, infrastructural, nanoeconomics, behavioral, production, innovation, and cultural and ethical criteria. The content of external and internal determinants is determined for each criterion separately.

Prospects for further research. The study of the main determinants of green competitiveness will form a range of appropriate strategies for its promotion. It is advisable to use these components as key guidelines, primarily related to internal components.

Keywords: sustainable development; green competitiveness; determinants; strategies; innovation.

Formulas: 0 , fig.: 0 , tabl.: 1 , bibl.: 20

Fuding.

This research was funded by the grant from the Ministry of Science of Ukraine № 0119 U101860 and № 0120 U102002.

\section{Анотація}

\section{Олена ЧИГРИН, Лілія ЛЮЛЬОВА, Марина САєНКО}

\section{ГОЛОВНІ ДЕТЕРМІНАНТИ СТАЛОЇ КОНКУРЕНТОСПРОМОЖНОСТІ}

Вступ. Розвиток підприємницького сектору характеризуються схильністю багатьох підприємств до просування екологічно орієнтованих стратеаій фрункціонування, реалізації виконання цілей сталого розвитку, що буде сприяти розв'язанню глобальних та локальних екологічних проблем, зниженню антропогенного навантаження на довкілля, економії ресурсів, фоормуванню конкурентоспроможного розвитку країн та підприємницького сектору в цілому.

Метою статmі $є$ вивчення наукових підходів до визначення основних фракторів та компонентів стійкої конкурентоспроможності, визначення ключових цілей (цільових груп) та детермінант, які визначать предметну основу відповідних маркетингових стратеаій для забезпечення зеленої конкурентоспроможності підприємств.

Результати. 3 метою формування стратегічних орієнтирів просування зеленої конкурентоспроможності в статті систематизовано наукові підходи до ї̈ 
дослідження, які включають маркетингові, технологічні, інноваційні, комунікаційні, стейкхолдерські, якісні, рівневі, фрінансові та етичні напрямки.

Автори підкреслюють, що процеси забезпечення екологічно орієнтованих конкурентних переваг багато в чому визначаються набором відповідних детермінант. В статmі запропоновано групувати відповідні детермінанти на дві групи, які будуть визначатися об'єктивними (зовнішніми) та суб'єктивними (внутрішніми) компонентами. Систему відповідних фракторів запропоновано класифікувати за управлінськими, фрінансовими, інфрраструктурними, наноекономічними, поведінковими, виробничими, інноваційними та культурноетичними критеріями. При цьому зміст екстернальних та інтернальних детермінант визначається для кожного критерію окремо.

Перспективи подальших досліджень. Дослідження головних детермінант зеленої конкурентоспроможності буде формувати коло відповідних стратегій ії просування. В якості ключових орієнтирів доцільно використовувати зазначені складові, пов'язані, в першу чергу, з інтернальними складовими.

Ключові слова: сталий розвиток; зелена конкурентоспроможність; детермінанти; стратегії; інновації.

Формули: 0, рис.: 0, табл.: 1, бібл.: 20.

\section{Фінансування.}

Це дослідження фрінансувалось грантом Міністерства освіти і науки України № 0119 U101860 and № 0120 U102002.

Introduction. Sustainable development of the business sector and individual companies can be achieved when companies meet the needs and desires of consumers without endangering the environment [1, 2]. Companies whose activities are based on the principles of environmentally oriented management and sustainable development implement environmental management systems and models, choosing at the same time strategies to ensure green competitive advantages [3, 4].

Studies of theoretical and methodological principles of forming and improving the competitiveness of enterprises [5] and competitive development strategies of modern companies focused on the implementation of the principles of sustainable development give the opportunity to conclude that the formation and development of green competitiveness is possible with appropriate determinants.

Given this, it is important to study the content and main determinants of green competitiveness.

Purpose. The purpose of the article is to study scientific approaches to determining the main factors and components of sustainable competitiveness, identifying key targets (target groups) and determinants that will determine the substantive basis of appropriate marketing strategies to ensure the green competitiveness of enterprises.

Results. Thus, scientists Hart L. and Milstein B. [6] emphasize that the overall level of green competitiveness can be achieved by ensuring the efficiency of enterprises, while meeting the needs and desires of consumers and the absence of negative externalities (economic damage from environmental pollution and depletion of natural resources). 
Representatives of green businesses traditionally choose ecologically oriented strategies of activity which are realized, for example, by the implementation of the enterprise of ecological management and audit $[7,8]$. This ensures compliance with environmental laws and regulations and strategically plans to achieve sustainable competitive advantages [9]. Focusing on gaining sustainable green competitive advantages, modern enterprises use the so-called "double-bottom line" or "triple-bottom-line models". [10]. The first group of business behaviour models characterizes the socially responsible behaviour of economic entities, taking into account social, economic and environmental factors, which will provide appropriate advantages of enterprises in the competitive environment as a whole and will contribute to green competitive advantages. The second group of models ("triple-bottomline models") takes into account environmental and social performance indicators. These types of models emphasize and determine the importance of sustainability in gaining competitive advantages or so-called green market positions [Singh, S., 2010].

A separate group of researchers with the Hartmann P and Ibanez V. [11] argues that, in the process of building green market positions or environmental competitive advantages, companies, in particular, should focus and take as a basis the interaction between emotional preferences of consumers and their specific features focused on environmental factors. In this case, for example, the formation of a green image and brand is possible through the use of appropriate green marketing strategies.

Scientific approaches $[12,13,14]$ determine the consumer motivation as a key determinant of providing green competitiveness. They determine a number of criteria that are dominant in consumer decision-making to buy:

- possibility of recycling;

- availability of environmentally friendly packaging;

- efficiency in production;

- environmental friendliness production and consumption of products or services;

- safety of consumption;

- ease of use and disposal;

- ecological image of the company. Relevant consumer inquiries are clear criteria for companies, which form the basis for the formation of an appropriate system of green marketing strategies, such as green branding, green alliances, greening of innovations, and in general the activities of companies $[15,16]$. Some scholars, for example, study the differentiation in the levels of the green focus of enterprises, how comprehensively the company provides greening of all economic processes [17, 18, 19].

Clearly focused green marketing strategies and appropriate tactical marketing tools will provide green competitive advantages generated by consumers' perception of a better offer [20].The analysis allowed to systematize the relevant research and assess the nature and content of the relationship of marketing components of the formation of green competitive advantages of enterprises (table 1).

Thus, the systematization of scientific directions of research of essence and maintenance of influence of green marketing on the formation of competitive advantages of the enterprises will allow to form conceptual bases of use of strategies of green marketing for formation and increase of green competitiveness of the enterprises. 
Systematization of theresearches of the green competitiveness

\begin{tabular}{|c|c|}
\hline Approach & Content \\
\hline 1. Marketing & $\begin{array}{l}\text { Taking into account the green marketing strategies of the competitive } \\
\text { orientation of the enterprise and its competitive advantages }\end{array}$ \\
\hline 2. Technologic & $\begin{array}{l}\text { Emphasized the direct correlation between the production of environmental } \\
\text { products, technological processes and competitive advantages of enterprises }\end{array}$ \\
\hline 3. Innovative & $\begin{array}{l}\text { The influence of green innovations on the creation of additional value of goods } \\
\text { is investigated }\end{array}$ \\
\hline 4. Communicative & $\begin{array}{l}\text { The influence of green marketing strategies on competitive advantages is } \\
\text { proved }\end{array}$ \\
\hline 5. Stakeholder & $\begin{array}{l}\text { Taking into account the impact of stakeholder behaviour on the competitiveness } \\
\text { of companies }\end{array}$ \\
\hline 6. Qualitative & $\begin{array}{l}\text { The influence of qualitative and meaningful characteristics of goods on } \\
\text { strengthening of green competitive advantages of the enterprises is } \\
\text { investigated }\end{array}$ \\
\hline 7. Level & $\begin{array}{l}\text { Study of differences in the activities of macro-, micro- and medium-sized } \\
\text { enterprises in terms of providing competitive advantage }\end{array}$ \\
\hline 8. Financial & The optimization of financial indicators with competitive advantages is proved \\
\hline 9. Ethic & $\begin{array}{l}\text { The formation of corporate environmental ethics is a prerequisite for ensuring } \\
\text { competitive advantage }\end{array}$ \\
\hline
\end{tabular}

Source: generated by the author

The processes of providing environmentally-oriented competitive advantages are largely determined by a set of appropriate determinants. We propose to group the relevant determinants into two groups, which will be determined by objective (external) and subjective (internal) components.

We propose to classify this system according to the following criteria, which will be the same for the two groups of determinants, but the content for each subgroup will be determined separately.

Thus, the criteria for classifying the determinants of green competitiveness include the following.

1. Management determinants. From the point of view of internal construction, they include the system of ecological management and audit, available strategies and corresponding tactics of ecological policy, ecological control and monitoring, ecologically oriented business planning. External management factors include the existing system of state regulation of environmental protection and resource conservation, the system of environmental standardization and certification of products and activities of enterprises, and state environmental control.

2. Financial determinants. The internal environment of the enterprise is characterized by the financial stability of the enterprise, the scale of financing of green production and environmentally oriented activities, the market value of the enterprise, the structure and value of securities of the enterprise. The external component is determined by the general financial and economic situation in the country, the level of public funding for environmental spending, the content and volume of support for green business.

3. Infrastructure environment determinants, from the point of view of the enterprise, are characterized by the presence and development of environmental and environmental 
infrastructure of the enterprise, which is responsible for energy and resource efficiency, conducting periodic and one-time procedures of internal environmental audit, departments responsible for green marketing and logistics.

4. Nano economic determinants. Internal factors are characterized by the composition of companies' owners (shareholders) of companies, enterprise management, heads of departments, and staff.

In the scientific literature, there is a separate concept of "nanoeconomics", which is associated with the activities of company managers, whose decisions are able to radically change the strategy of the enterprise in a market environment. The key changes that can ensure the functioning of the nano economy of companies can be systematized as follows:

- increase of ecological responsibility of companies, encouragement of ecologically oriented business initiative;

- the transition of enterprises from a passive position in solving environmental problems, which is determined only by the requirements of environmental legislation, to a proactive position, which is largely determined by conscious environmentally-oriented own goals and objectives;

- expanding the boundaries of initiative environmental activities of companies, shifting priorities to the causes and sources of negative impact on the environment;

- understanding and implementation of existing relationships between the results of environmental activities and opportunities to attract investment, production development, resource savings, reduce production costs, increase the environmental friendliness of products and their competitiveness;

- activation of internal unused economic reserves and opportunities to ensure green competitiveness;

- open declaration and proclamation by companies of ecological goals, programs and achievement of ecological and economic results, including negative consequences of the activity;

- active cooperation with all stakeholders, including investors, shareholders, business partners, consumers, the public and competitors.

The external component is formed by stakeholders represented by the person of the state, shareholders of enterprises, affiliates, consumers of green goods and services, contractors and competitors of the enterprise.

5. Behavioural determinants at the enterprise level are conditioned by the formation of a green image of the company, by the system of analysis of the role of behavioural factors and cognitive processes in decision-making by consumers of green products, by the motivation of environmental activities and resource conservation and by formation of green competitive advantages in the market. The external side of the influence of behavioural determinants of the formation of green competitiveness is represented by the level of social perception of environmental innovations and green goods by consumers, the peculiarities of the psychology of consumer behaviour; motivation of green consumption, framing processes and anomalies of consumer behaviour.

6. Production determinants. The internal component of the enterprise will be determined by the available production potential of the enterprise, the possibility of implementing green innovations, resource intensity of production, the level of anthropogenic pressure on the 
environment, and staff qualifications. The external environment for these determinants is characterized by the level of development of scientific progress and its perception in society, the development and availability of green technologies.

7. Innovative determinants. Determining the relevant determinants is important because all environmentally friendly products are innovative in content and technology used in their production. Opportunities for development and production of innovations at the enterprise are determined by a number of factors. Thus, the basic can include the size of the enterprise (small, medium, large). In terms of flexibility of response and speed of implementation of green innovations, of course, small and medium enterprises have significant advantages, both in terms of organizational and managerial processes, as well as technical and financial capabilities.

8. Cultural and ethical determinants. The success of the formation of green competitiveness will be determined by the presence of environmentally oriented management, corporate environmental ethics and culture. The level of integrity of the company in the market and the compliance of the declared environmental benefits of green goods with the real quality of goods are also important. The external component will characterize the presence in society of environmental standards, voluntary and mandatory green regulations, the level of green washing of competing companies. The general level of ecological culture and moral and psychological climate in society are important.

Conclusion. The formation and development of green competitiveness can be ensured as a result of environmentally oriented development of enterprises of various organizational and legal forms of management. The studied main determinants of green competitiveness should form a circle of appropriate drivers of its promotion, which will determine the managerial, financial, infrastructural, stakeholder, behavioural, technological, innovative, cultural and ethical aspects of modern enterprises.

\section{References}

1. Chygryn, O.Yu., \& Scherbak, A.S. (2011). Analysis of the problem of the introduction the environmentally friendly production in Ukraine. The mechanism of economic regulation. 1, 235-241[In Ukranian].

2. Chygryn, O., Pimonenko, T., Luylyov, O., \& Goncharova, A. (2018). Green Bonds like the Incentive Instrument for Cleaner Production at the Government and Corporate Levels Experience from EU to Ukraine. Journal of Advanced Research in Management, 9 (7), 1443-1456 [In English].

3. Hens, L., Melnyk L., Matsenko, O., Chygryn, O. \& Gonzales, C. C. (2019). Transport Economics and Sustainable Development in Ukraine. Marketing and Management of Innovations, 3, 272-284. Retrieved from http://doi.org/10.21272/mmi.2019.3-21 [In English].

4. Panchenko, V., Harust, Yu., Us, Ya., Korobets, O., \& Pavlyk, V. (2020). EnergyEfficient Innovations: Marketing, Management and Law Supporting. Marketing and Management of Innovations, 1, 256-264. Retrieved from http://doi.org/10.21272/ mmi.2020.1-21 [In English]. 
5. Pimonenko, T., Lyulyov, O., Chygryn, O., \& Palienko, M. (2018). Environmental Performance Index: relation between social and economic welfare of the countries. Environmental Economics, 9(3), 1 [In English].

6. Hart, L.S., \& Milstein, B.M. (2003). Creating sustainable value. Academy of Management Executive. 17, 56 - 67 [In English].

7. Rybina, O.I. (2020). Formation of the mechanism of ecological marketing in the context of the concept of sustainable development. Effective economy. 1. Retrieved from http://www.economy.nayka.com.ua/pdf/1_2020/78.pdf [In Ukranian].

8. Syhyda L.O. (2013). The influence of the marketing environment of the enterprise on the process of developing a marketing policy of distribution. - Economic annals. XXI, 7-8(2), 28-32 [In Ukranian].

9. Miles, M.P., \& Covin, J.G. (2000). Environmental Marketing: A source of reputational, competitive, and financial advantage. Journal of Business Ethics. 23, 299-311 [In English].

10. Bryson, R.J., \& Lombardi, R. (2009). Balancing product and process sustainability against business profitability: Sustainability as a competitive strategy in the property development process. Business Strategy and the Environment. 18, 97-107 [In English].

11. Hartmann, P., Ibáñez, V.A.; \& Sainz, F.J.F. (2005). Green branding effects on attitude: Functional versus emotional positioning strategies. Marketing Intelligence and Planning. 23, 9-29 [In English].

12. Coleman, L.J., Bahnan, N., Kelkar, M., \& Curry, N. (2011). Walking the walk: How the theory of reasoned action explains adult and student intentions to go green. Journal of Applied Business Research. 27, 107-116 [In English].

13. Olasiuk, H., \& Bhardwaj, U. (2019). An Exploration of Issues Affecting Consumer Purchase Decisions Towards Eco-friendly Brands. Marketing and Management of Innovations, 2, 173-184. Retrieved from http://doi.org/10.21272/mmi.2019.2-15 [In English].

14. Paskannaya, T., \& Shaban, G. (2019). Innovations in Green Logistics in Smart Cities: USA and EU Experience. Marketing and Management of Innovations, 1, 173-181. Retrieved from http://doi.org/10.21272/mmi.2019.1-14 [In English].

15. Rosokhata, A. (2014). Classification of methods of economic and mathematical modeling in forecasting the innovative development of industrial enterprises. Current achievements of European science. X International scientific-practical conference. Sofia. 39-42 [In Ukranian].

16. Saher, L.Yu., Syhyda, L.O., \& Gryshova, I. (2018). Current state and prospects for the development of innovative activity of industrial enterprises in Ukraine and the world. Innovative Management: theoretical, methodical and applied grounds. 1st edition, Prague Institute for Qualification Enhancement: Prague, 83-96 [In English].

17. Pimonenko, T., Chyhryn, O., \& Liulov, O. (2018). Green Entrepreneurship as an Integral Part of the National Economy Convergence. National Security \& Innovation Activities: Methodology. Policy and Practice: a monograph. P. 358-366 [In English]. 
18. Tielietov, O.S., \& Letunovska N.Ye. (2014). Organizational and economic mechanism of industrial enterprises social infrastructure management. Actual problems of economics. 10, 329-337 [In English].

19. Yevdokimov, Y., Chygryn, O., Pimonenko, T., \& Lyulyov, O. Biogas as an alternative energy resource for Ukrainian companies: EU experience. Innovative Marketing, 14, 7-15 [In English].

20. Porter, M.E., \& van der Linde, C. (1995). Toward a New conception of the environment-competitiveness relationship. Journal of Economic Perspectives. 9, 97-118 [In English].

Article received May 18, 2020

Статтю отримано 18 травня 2020 p. 